\title{
Preliminary Study on Pasta Samples Characterized in Antioxidant Compounds and Their Biological Activity on Kidney Cells
}

\author{
Federico Di Marco ${ }^{1}$ (D) Francesco Trevisani ${ }^{1}$, Pamela Vignolini ${ }^{2}$, Silvia Urciuoli ${ }^{2}$, Andrea Salonia ${ }^{1,3}$ (D) $^{1}$ \\ Francesco Montorsi ${ }^{1,3}$, Annalisa Romani ${ }^{2}$, Riccardo Vago ${ }^{1,3, *}$ and Arianna Bettiga ${ }^{1, *}$ \\ 1 Division of Experimental Oncology, Urological Research Institute (URI), IRCCS San Raffaele Scientific \\ Institute, 20132 Milan, Italy; federico.dimarco91@gmail.com (F.D.M.); trevisani.francesco@hsr.it (F.T.); \\ salonia.andrea@hsr.it (A.S.); montorsi.francesco@hsr.it (F.M.) \\ 2 PHYTOLAB (Pharmaceutical, Cosmetic, Food Supplement, Technology and Analysis), DiSIA, \\ University of Florence, 50019 Sesto Fiorentino, Italy; pamela.vignolini@unifi.it (P.V.); \\ silvia.urciuoli@gmail.com (S.U.); annalisa.romani@unifi.it (A.R.) \\ 3 Department of Urology, Università Vita-Salute San Raffaele, 20132 Milan, Italy \\ * Correspondence: vago.riccardo@hsr.it (R.V.); bettiga.arianna@hsr.it (A.B.)
}

\section{check for} updates

Citation: Di Marco, F.; Trevisani, F.; Vignolini, P.; Urciuoli, S.; Salonia, A.; Montorsi, F.; Romani, A.; Vago, R.; Bettiga, A. Preliminary Study on Pasta Samples Characterized in Antioxidant Compounds and Their Biological Activity on Kidney Cells Nutrients 2021, 13, 1131. https:// doi.org/10.3390/nu13041131

Academic Editor:

Margarida Castell Escuer

Received: 9 March 2021

Accepted: 26 March 2021

Published: 30 March 2021

Publisher's Note: MDPI stays neutral with regard to jurisdictional claims in published maps and institutional affiliations.

Copyright: (c) 2021 by the authors. Licensee MDPI, Basel, Switzerland. This article is an open access article distributed under the terms and conditions of the Creative Commons Attribution (CC BY) license (https:// creativecommons.org/licenses/by/ $4.0 /)$.

\begin{abstract}
Pasta is one of the basic foods of the Mediterranean diet and for this reason it was chosen for this study to evaluate its antioxidant properties. Three types of pasta were selected: buckwheat, rye and egg pasta. Qualitative-quantitative characterization analyses were carried out by HPLC-DAD to identify antioxidant compounds. The data showed the presence of carotenoids such as lutein and polyphenols such as indoleacetic acid, (carotenoids from 0.08 to $0.16 \mathrm{mg} / 100 \mathrm{~g}$, polyphenols from 3.7 to $7.4 \mathrm{mg} / 100 \mathrm{~g}$ ). To assess the effect of the detected metabolites, in vitro experimentation was carried out on kidney cells models: HEK-293 and MDCK. Standards of $\beta$-carotene, indoleacetic acid and caffeic acid, hydroalcoholic and carotenoid-enriched extracts from samples of pasta were tested in presence of antioxidant agent to determine viability variations. $\beta$-carotene and indoleacetic acid standards exerted a protective effect on HEK-293 cells while no effect was detected on MDCK. The concentrations tested are likely in the range of those reached in body after the consumption of a standard pasta meal. Carotenoid-enriched extracts and hydroalcoholic extracts showed different effects, observing rescues for rye pasta hydroalcoholic extract and buckwheat pasta carotenoidenriched extract, while egg pasta showed milder dose depending effects assuming pro-oxidant behavior at high concentrations. The preliminary results suggest behaviors to be traced back to the whole phytocomplexes respect to single molecules and need further investigations.
\end{abstract}

Keywords: pasta; Mediterranean diet; polyphenols; carotenoids; antioxidant compounds; kidney health; HPLC/DAD analyses

\section{Introduction}

Despite that there is no unique definition of the Mediterranean diet-due to the variations and adaptations in culinary traditions not only around the Mediterranean area but also around the world [1] — the Mediterranean diet may be thought of as having several components that meet important criteria for a healthy diet: low content of saturated fatty acids, high content of composite carbohydrates, dietary fiber and antioxidant molecules, and abundance in vegetables.

It is difficult to establish which foods, or active ingredients therein contained, of the Mediterranean diet are most responsible for the health benefits; accumulating data suggest that its main benefits lie in the combination of the complex and wide variety of different nutrients interacting synergistically and additively [2].

In recent years, the growing literature (observational studies and randomized control trials) has demonstrated the health benefits associated with the Mediterranean diet, 
reducing risk of developing multiple chronic diseases as cardiovascular diseases [3-5], diabetes [6-10], cancer [11,12], obesity [13-15] or cognitive health [16-19] and increasing life expectancy [20].

Improvements in blood pressure [21], lipid profile [22,23], insulin resistance [24], and protection against oxidative stress, inflammation, platelet aggregation and endothelial dysfunction [25-28] seem to be the mechanisms of action responsible for the beneficial effects on the general health. All these biological effects promoted by the adherence to the Mediterranean lifestyle could be relevant not only for the above-mentioned chronic diseases, but also for the prevention of renal decay in general population. Chronic kidney disease (CKD) represents a global public health problem, affecting over 750 million persons worldwide and acts often silent and unhindered thanks to its asymptomatic clinical presentation. Different lines of evidence have underlined the strong relationship between Mediterranean diet and renal preservation [29].

Considering all the above-mentioned effects as risk factors for the decline of the renal function, the kidney can be considered one of the primary targets.

A recent meta-analysis of cohort studies has shown that plant-based diets such as the Mediterranean diet or dietary approach to stop hypertension (DASH) diet was associated with a lower risk of incident CKD and albuminuria in the general population [30]. One explanation could be that fruit and vegetables contain bioactive compounds protecting against inflammation and endothelial dysfunction that promote dynamic changes of filtration fraction, resulting in a progressive reduction of the glomerular filtration rate, extracellular fluid volume expansion, abnormal ion balance, and renal hypoxia, ultimately leading to loss kidney function [31-33]. Moreover, the increase of vegetable, fruit, cereal and legumes consumption may have led to a decrease in animal protein consumption positively influencing acid-base balance and glomerular hemodynamics of the kidney, protecting it to glomerular sclerosis and loss of function [34-37].

Despite this, there are several studies with contrasting data for the impact of a high protein diet on renal function decline in the general population [38-41] growing evidence suggest that the protein source plays an important role to preservation of renal function, and that a shift from animal to plant source of protein might be beneficial [42,43].

Pasta is one of the most consumed foods in the world and is one of the staple foods of the Mediterranean diet. Traditionally, Italy is the main producer and leader of the pasta consumption, even if pasta is consumed worldwide for low cost, palatability, and the longer shelf life than other bakery products [44]. Pasta is a good source of carbohydrates and energy (100 $\mathrm{g}$ of cooked pasta contains about $31 \mathrm{~g}$ of carbohydrates and about $158 \mathrm{kcal}$ ) but it is typically low in lipids, proteins, phosphorus and potassium that are nutrient components restricted in the most renal diets for kidney disease (available online at https: / fdc.nal.usda.gov, accessed on 1 December 2020). Naturally enriched wheat pastas, which represent the majority of commercially available pastas, also offer good levels of thiamin, riboflavin, niacin, folate, iron, and selenium, as well as polyphenols. Furthermore, pasta is always consumed in combination with other food items that could be considered as a stronger source of polyphenols, such as olive oil and vegetables. Pasta is usually produced with durum wheat semolina, due to its excellent rheological properties, the superior color of the pasta, the quality of cooking and the acceptance by the consumer, but lately pasta can also be produced starting from other cereals such as rice, buckwheat, rye, spelled.

In recent years, consumers have become more aware that a balanced diet, such as the Mediterranean one, can positively affect health, which is why the food industry tries to meet these demands by producing quality and functional foods and food ingredients.

Despite fortified foods have been produce for healthy purpose, people could be induced to assume them instead of a balanced diet. This is a so important topic to prompt the FDA to publish an ad hoc document entitled "FDA's fortification policy" to give an answer on one side to the food industry and on the other to the academic world [44]. 
Balanced, adequate and varied diet is an important step towards a happy and healthy lifestyle without the risk of overloading with some added component contained in fortified food. Precisely for this reason non-traditional cereals and pseudo-cereals have been rediscovered which have paved the way for their use as functional food ingredients as they possess some nutritional and functional qualities that are absent or lacking in traditional cereals. Buckwheat and rye are a rich source of phytochemicals such as polyphenols, compounds that are strongly correlated with antioxidant activities [45,46].

Launched in March 2005, the MOLI-SANI Project involved about 25,000 citizens residing in Molise (Italy), to evaluate environmental and genetic factors underlying cardiovascular diseases, tumors and neurodegenerative diseases. According to a study from the MOLI-SANI project, pasta intake is associated with a lower BMI and lower levels of central obesity. Many studies have confirmed that high calorie diets lead to weight gain and not a diet that includes carbohydrates. In fact, if the portion of pasta is correct and the sauce is not too caloric, a plate of pasta can have a caloric content that respects the daily energy requirement [47]. Pasta is held in high regard as its characteristics have been associated not only with body weight control, but also with several positive health properties [48]. A randomized, controlled study conducted on healthy subjects showed that rye-based products improve glycemic regulation, increase intestinal hormones involved in the regulation of appetite and metabolism. Rye reduces postprandial appetite levels by reducing the desire to eat at subsequent meals, increasing satiety and reducing hunger by increasing the satiety hormones GLP-1 (glucagon-like peptide-1) and peptide YY (PYY). A lower postprandial glucose response was observed in a group of people consuming rye-based foods compared to a group of subjects consuming refined wheat. This happens because rye is a low glycemic index cereal that can also be used in diabetic patients [49]. Rye can improve the plasma lipid profile, in fact the intake of whole rye is inversely associated with the concentration of LDL cholesterol, the LDL/HDL ratio and the concentration of triglycerides. This effect is due to the presence of fibers and $\beta$-glucans [50].

Pasta is well known as a source of carbohydrates, but it can also contain minor compounds, such as carotenoids [51], especially lutein, and other antioxidant species such as polyphenols. These bioactive molecules can be enriched in different types of pasta, depending on the raw materials. For instance, the carotenoids content of durum wheat is higher than that of bread wheat [52] and the level of antioxidants can be increased by incorporating bran fraction and entire kernel of durum wheat to pasta products [53]. Buckwheat is a substantial source of phenolic compounds, vitamins and essential amino acids [54], while the addition of egg in the preparation of the pasta conveys carotenoids and lutein. Carotenoids participate in prevention activity, especially in inflammation syndrome and their role is due to their antioxidant properties [55] against free radicals and singlet oxygen [56]. Pasta contains different types of antioxidant molecules and for the frequent consumers, large consumption can be considered an important source of such healthy compounds.

Here we show that different types of pasta namely buckwheat, rye and egg pasta, contain various amounts of antioxidant compounds, which have a role to improve renal cell viability at a steady state or upon the induction of oxidative stress.

\section{Materials and Methods}

\subsection{Samples}

Three samples of cooked pasta were analyzed and tested: one sample of wholemeal buckwheat pasta (1), one sample of wholemeal rye pasta (2) and one sample of egg pasta of stone-ground durum wheat flour (3).

\subsection{Pasta Samples Preparation}

Totals of $50 \mathrm{~g}$ of whole meal buckwheat pasta or whole meal rye pasta were cooked in $500 \mathrm{~mL}$ of water for $7 \mathrm{~min} ; 50 \mathrm{~g}$ of egg pasta of stone-ground durum wheat flour were cooked in $500 \mathrm{~mL}$ of water for $1 \mathrm{~min}$, as indicated by the manufacturer. 
To obtain extracts enriched in carotenoids, $10 \mathrm{~g}$ of cooked pasta were dissolved in $100 \mathrm{~mL}$ acetone, cold sonicated for $30 \mathrm{~min}$. The sample was centrifuged for $5 \mathrm{~min}$ at $5000 \mathrm{rpm}$, the supernatant has been dry evaporated with a rotary evaporator and the residue was dissolved in acetone or DMSO depending on the downstream analysis. To obtain extracts enriched in polyphenols, $10 \mathrm{~g}$ of each sample of cooked pasta were dissolved in $50 \mathrm{~mL}$ of 70:30 $\mathrm{EtOH} / \mathrm{H}_{2} \mathrm{O}$ at $\mathrm{pH}$ 3.2. The samples were shaken for $24 \mathrm{~h}$, centrifuged for $5 \mathrm{~min}$ at $1400 \mathrm{rpm}$. The sample was centrifuged for $5 \mathrm{~min}$ at $5000 \mathrm{rpm}$ and the supernatant was collected and analyzed in HPLC-DAD, while an aliquot was dry evaporated, and the residue dissolved in DMSO for cell treatment.

\subsection{HPLC-DA-MS Analysis}

Quali-quantitative analyses of carotenoids and polyphenols were carried out using an HP 1100 liquid chromatography equipped with a DAD detector and managed by an HP 9000 workstation (Agilent Technologies, Palo Alto, CA, USA) and linked to a mass spectrometer with an API/electrospray interface (Agilent Technologies). The mass spectrometer operating conditions were as follows: gas temperature, $350{ }^{\circ} \mathrm{C}$; nitrogen flow rate, $11.0 \mathrm{~L} / \mathrm{min}$; nebulizer pressure, $40 \mathrm{psi}$; quadrupole temperature, $100{ }^{\circ} \mathrm{C}$; and capillary voltage, $4000 \mathrm{~V}$. The mass spectrometer was operated in positive and negative modes at 80-180 eV.

Compounds were separated using a $250 \times 4.6 \mathrm{~mm}$ i.d, $5 \mu \mathrm{m}$ LUNA C18 column (Phenomenex, Torrance, CA, USA). UV/Vis spectra were recorded in the 190-600 nm range and the chromatograms were acquired at 250, 280, 330, 350 and $450 \mathrm{~nm}$. The samples were analyzed by gradient elution at a flow rate of $0.8 \mathrm{~mL} / \mathrm{min}$. The mobile phase for carotenoids was a multistep linear solvent gradient system (solvent A: acetone, solvent B: $\mathrm{H}_{2} \mathrm{O}$, pH 3.2 by formic acid), starting from $80 \%$ acetone up to $100 \%$ in $30 \mathrm{~min}$. polyphenols were eluted using the following gradient: from $90 \% \mathrm{H}_{2} \mathrm{O}$ (adjusted to $\mathrm{pH} 3.2$ by formic acid) to $100 \% \mathrm{CH}_{3} \mathrm{CN}$ in 40 min. All solvents used were of HPLC grade purity (BDH Laboratory Supplies, Poole, UK).

\subsection{Quantitative Analysis}

Quantification of individual polyphenolic compounds was directly performed by HPLC-DAD using a five-point regression curve $\left(R^{2} \geq 0.998\right)$ in the range of 0-30 $\mu$ g on the basis of authentic standards. In particular, flavonols were determined at $350 \mathrm{~nm}$ using quercetin 3-O-glucoside as reference compound while caffeic acid derivatives were determined at $330 \mathrm{~nm}$ using clorogenic acid as reference compound and indoleacetic acid derivative at $280 \mathrm{~nm}$ using 3 indoleacetic acid (Sigma-Aldrich, St. Louis, MO, USA). Carotenoids were determined at $450 \mathrm{~nm}$ using $\beta$ beta-carotene as reference compound (Extrasynthese, Lione, Francia). In all cases, actual concentrations of the derivatives were calculated after applying corrections for differences in molecular weight.

\subsection{Total Phenolic Content}

The total phenolic content was determined using the Folin-Ciocalteu method, described by Singleton et al. [57] and slightly modified according to Dewanto et al. [58]. To $125 \mu \mathrm{L}$ of the suitably diluted sample extract, $0.5 \mathrm{~mL}$ of deionized water and $125 \mu \mathrm{L}$ of the Folin-Ciocalteu reagent were added. The mixture was kept for $6 \mathrm{~min}$ and then $1.25 \mathrm{~mL}$ of a $7 \%$ aqueous $\mathrm{Na}_{2} \mathrm{CO}_{3}$ solution were added. The final volume was adjusted to $3 \mathrm{~mL}$ with water. After $90 \mathrm{~min}$, the absorption was measured at $760 \mathrm{~nm}$ against water as a blank. The amount of total phenolics is expressed as gallic acid equivalents (GAE, mg gallic acid/100 g sample) through the calibration curve of gallic acid. The calibration curve ranged from 20 to $500 \mu \mathrm{g} / \mathrm{mL}\left(\mathrm{R}^{2}=0.9969\right)[57,58]$. 


\subsection{Cell Culture}

Human Embryonic Kidney 293 (HEK-293) cells and Madin-Darby canine kidney (MDCK) cells were cultured in DMEM supplemented with GlutaMAX, 10\% $(v / v)$, fetal bovine serum, $100 \mathrm{U} / \mathrm{mL}$ penicillin and $100 \mu \mathrm{g} / \mathrm{mL}$ streptomycin at $37{ }^{\circ} \mathrm{C}$ with $5 \% \mathrm{CO}_{2}$.

\subsection{MTT Assay}

5000 cells/well MDCK and HEK-293 cells were seeded in 96 well plates and allowed to adhere for $24 \mathrm{~h}$. For viability studies, cells were incubated for $24 \mathrm{~h}$ to $72 \mathrm{~h}$ with betacarotene, indole-3-acetic acid, caffeic acid (in DMSO) and pasta extracts alone or in presence of magnesium monoperoxyphtalate (MMPP, Sigma-Aldrich, St. Louis, MO, USA). DMSO in the medium at equal concentrations to those used for the tested compounds was used for untreated samples. The tested concentration for the standards were ranging from $2 \mathrm{pM}$ to $10 \mu \mathrm{M}$, while for MMPP from 0.001 to $0.05 \mathrm{mg} / \mathrm{mL}$. Cell viability were measured 3-(4,5dimethylthiazol-2-yl)-2,5-diphenyl tetrazolium bromide (MTT, Sigma-Aldrich, St. Louis, $\mathrm{MO}$, USA). The plates were incubated at $37^{\circ} \mathrm{C}$ for $1 \mathrm{~h}$ and then the Formazan produced by the MTT reduction was solubilized in DMSO. Absorbance was determined on a micro plate reader (Mithras LB 940-Berthold) at $570 \mathrm{~nm}$. The percentage of cell viability was calculated using the ratio $\mathrm{Abs}_{\mathrm{TEST}} / \mathrm{Abs}_{\mathrm{CTRL}}$.

\subsection{Statistical Analysis}

Each experiment was performed in quadruplicate and repeated at least three times. Differences in viability percentages were assessed using paired Student's $t$ test and two-way ANOVA followed by a post-hoc test with Holm's correction for multiple comparison over concentrations metabolites $(p<0.05)$. Results were expressed as mean \pm standard error and the analysis were performed by R-Studio environment [59] for R version 3.6.3 [60] using the package "Tidyverse" [61].

\section{Results and Discussion}

\subsection{Determination of the Chemical Quality of Pasta Samples}

The nutritional information of a food allows making informed food and dietary choices. Pasta is traditionally prepared from semolina but even with other cereals, all contain starch as a principal constituent followed by protein, fat, vitamins, minerals and bioactive compounds [62]. In Table S1 are reported the nutritional data.

To compare the nutritional values of several types of pasta enriched in bioactive compounds due to the different source of cereals or to the supplementation of specific ingredients, we analyzed buckwheat pasta, rye pasta and egg pasta. In order to obtain extracts enriched in the various subclasses of compounds present in the pasta samples, both hydroalcoholic and acetone extractions were carried out and analyzed. Individual polyphenols were tentatively identified using data from HPLC-DAD-MS analysis by comparison and combination of their retention times and mass spectrometry and UV spectra (see Figures S1-S5 for same example of MS spectra) and comparing results with standards (kaempferol, quercetin, rutin and ferulic acid) and previous bibliographic works. In particular, in hydroalcoholic extracts, flavonoids, caffeic and indoleacetic acid derivatives were identified (Table 1): the indoleacetic acid derivative is the main compound as described before even for semolina. [63]. Considering relative compositions, buckwheat pasta showed higher levels of flavonoids, in particular quercetin derivatives are the main flavonols as previously reported in buckwheat $[64,65]$, and negligible presence of caffeic acid derivatives; rye pasta showed higher levels of caffeic acid derivatives, in particular ferulic acid [66] and low content of flavonoids; egg pasta presented only low concentration of flavonoids (apigenin derivative [67]) and no presence of caffeic acid derivatives. 
Table 1. Caffeic derivatives (caffeic der), flavonoids and indoleacetic acid derivative (IAA der) content in cooked pasta samples. Data are the mean of three determinations (standard deviation $<5 \%$ ). The percentage of single classes of identified compounds is shown in brackets.

\begin{tabular}{cccc}
\hline & $\begin{array}{c}\text { IAA der } \\
\mathbf{m g / 1 0 0 ~} \mathbf{~ ( \% )}\end{array}$ & $\begin{array}{c}\text { Flavonoids } \\
\mathbf{m g} / \mathbf{1 0 0} \mathbf{g} \mathbf{( \% )}\end{array}$ & $\begin{array}{c}\text { Caffeic der } \\
\mathbf{~ m g / 1 0 0 ~} \mathbf{~ ( \% )}\end{array}$ \\
\hline buckwheat pasta (1) & $2.7 \pm 0.086(37)$ & $4.1 \pm 0.114(56)$ & $0.6 \pm 0.025(7)$ \\
rye pasta (2) & $1.6 \pm 0.041(44)$ & $0.6 \pm 0.019(17)$ & $1.5 \pm 0.052(39)$ \\
Egg pasta (3) & $4.8 \pm 0.110(85)$ & $0.8 \pm 0.021(15)$ & - \\
\hline
\end{tabular}

As an example, the chromatographic profiles of cooked pasta samples, recorded at $350 \mathrm{~nm}$, are presented in Figure 1. The figure reveals the qualitative composition of the samples analyzed.

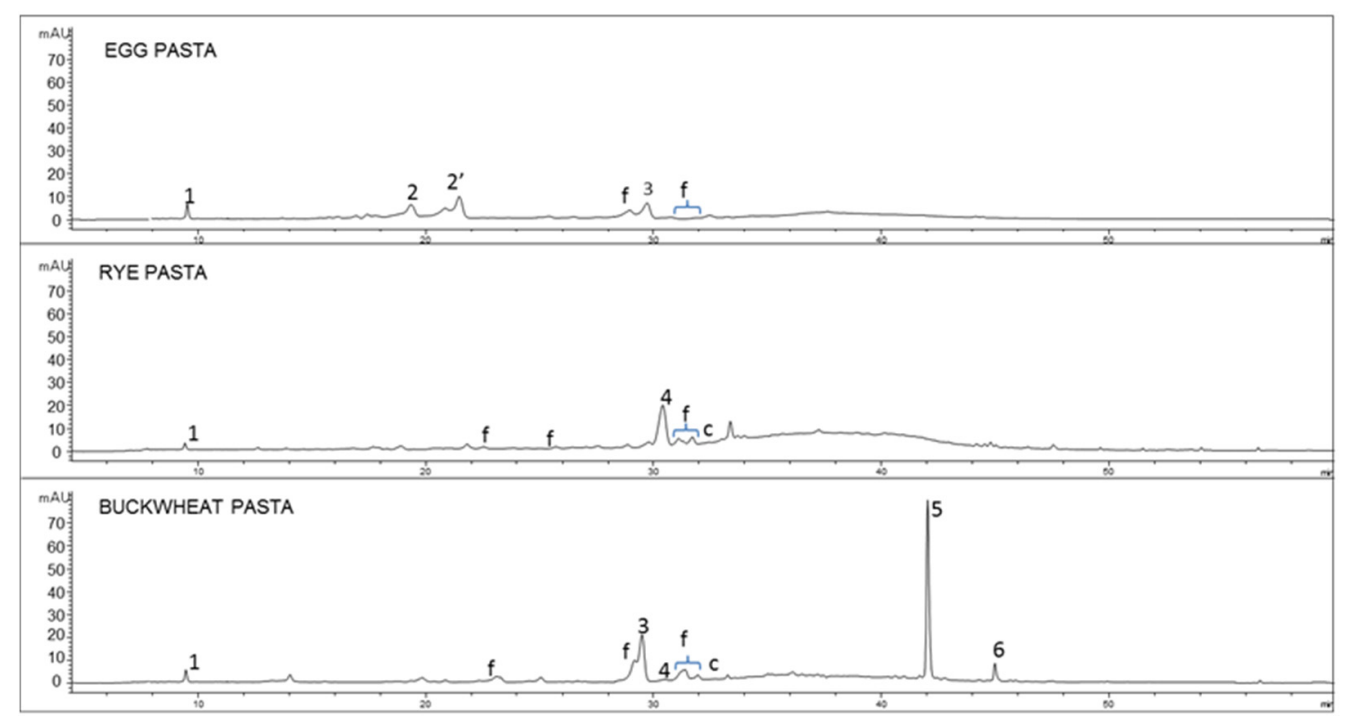

Figure 1. Chromatographic profile (Relative abundance as y axis vs. Retention time as $x$ axis) acquired by HPLC-DAD $(350 \mathrm{~nm})$ of the hydroalcholic extracts of cooked buckwheat pasta, rye pasta, egg pasta. Identified compounds: $1=$ indoleacetic acid derivative, $2,2^{\prime}=$ apigenin diglicosides, $3=$ rutin, $4=$ ferulic acid, $5=$ quercetin, $6=$ kaempferol, $\mathrm{f}=$ flavonoids.

Even carotenoids were pointed out in egg pasta and buckwheat pasta, and Figure 2 shows the HPLC-DAD chromatogram $(450 \mathrm{~nm})$ of the acetone extract of cooked egg pasta sample.

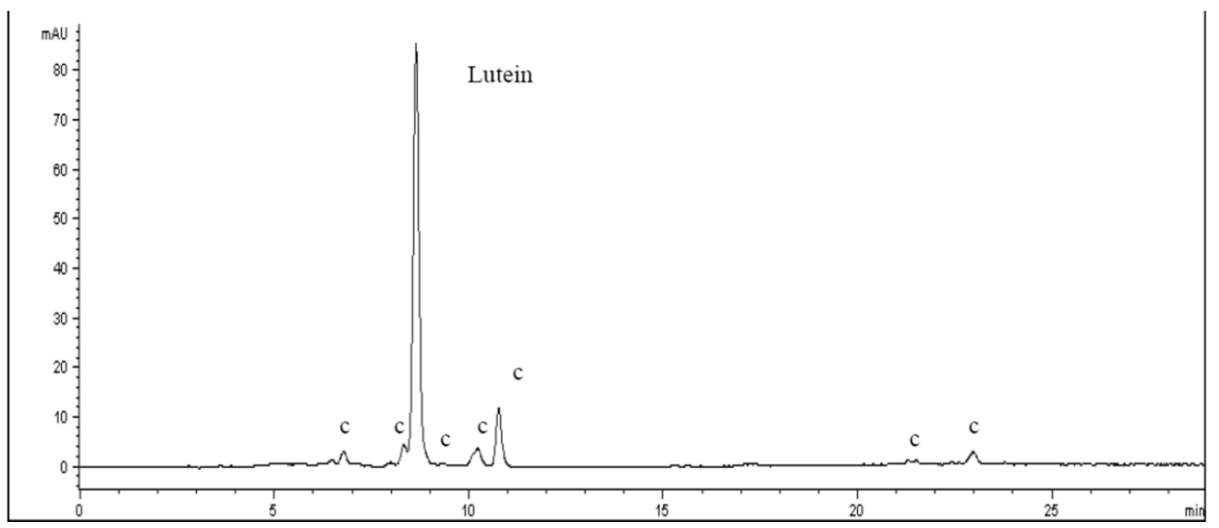

Figure 2. Chromatographic profile (Relative abundance as y axis vs. Retention time as $x$ axis) at $450 \mathrm{~nm}$ of a carotenoid acetone fraction of egg cooked pasta extract. Identified compounds: Lutein, $\mathrm{c}=$ carotenoid derivatives. 
Lutein was the main carotenoid identified in the acetone extracts, with similar relative content with respect to the overall carotenoids species, as shown in Table 2, in line with previous studies [68]. Carotenoids were not detected in rye pasta.

Table 2. Carotenoids and lutein content in cooked pasta samples. Data are the mean of three determinations (standard deviation $<5 \%$ ).

\begin{tabular}{ccc}
\hline & Carotenoids $\mathbf{~ m g / 1 0 0 ~ g ~}$ & Lutein $\mathbf{~ m g / 1 0 0 ~} \mathbf{g}$ \\
\hline buckwheat pasta (1) & $0.08 \pm 0.002$ & $0.06 \pm 0.002$ \\
\hline Egg pasta (3) & $0.16 \pm 0.006$ & $0.11 \pm 0.004$ \\
\hline
\end{tabular}

The presence of antioxidant secondary metabolites has been evaluated in the pasta samples as well (Table 3). The total antioxidant capacity of biocomponents, likely due to the activity of phenol/polyphenol was assessed and the amount of such molecules was deduced.

Table 3. Total phenolic content (GAE, mg gallic acid/100g, Folin-Ciocalteu method) in cooked pasta samples. Data are the mean of three determinations (standard deviation $<5 \%$ ).

\begin{tabular}{cc}
\hline & GAE, $\mathbf{~ m g ~ G a l l i c ~ A c i d / 1 0 0 ~ g ~ P a s t a ~}$ \\
\hline buckwheat pasta (1) & $33.23 \pm 0.598$ \\
rye pasta (2) & $21.03 \pm 0.273$ \\
egg pasta (3) & $11.55 \pm 0.1848$ \\
\hline
\end{tabular}

Buckwheat pasta sample has higher values than other pasta's samples in terms of total phenolic content.

\subsection{Effect of Indole-3-Acetic Acid, $\beta$-Carotene and Caffeic Acid on Cells Viability}

Mediterranean diet has been recognized as a source of anti-oxidant molecules, which protect the organism against oxidative stress and support the healthy status [2]. Therefore, we wondered whether the biomolecules detected in our pasta samples can affect cell viability and at which extent. We used HEK-293 and MDCK healthy kidney cells to determine the activity of indoleacetic acid, $\beta$-carotene and caffeic acid standard compounds. The kidney is especially susceptible to oxidative stress and the accumulation of free radicals leads to renal impaired function [69]. Cells were incubated with scalar concentration of the standard compounds and the cell viability was measured at different time points (Figure 3 and Figure S6).
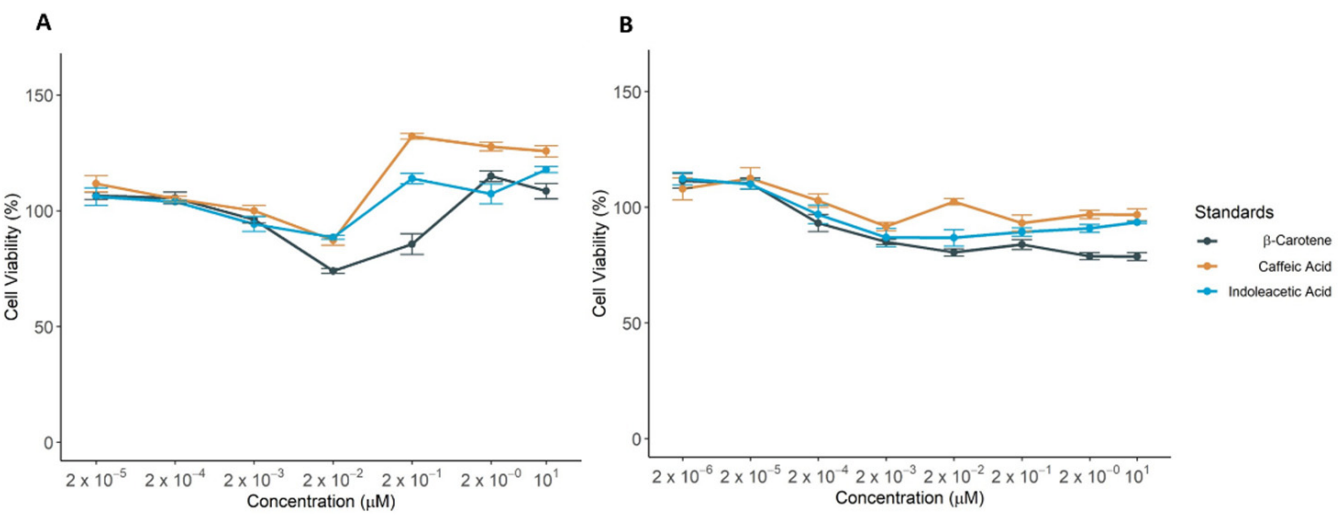

Figure 3. Detection cell viability of HEK-293 (A) and MDCK (B) incubated with increasing amount of indoleacetic acid, $\beta$-carotene and caffeic acid for 24 (B) or $72 \mathrm{~h}$ (A). Reported values correspond to mean of cell viability with standard error over three biological replicates. The percentage of cell viability was calculated using the ratio $\mathrm{Abs}_{\mathrm{TEST}} / \mathrm{Abs}_{\mathrm{CTRL}}$. 
They were found not to exert any toxic effect on HEK-293 cells for all the tested concentrations at times of incubation. Only $\beta$-carotene reduced cell viability in a u-shape manner on HEK-293 cells and in a dose-dependent manner in MDCK cells (Figure 3). Remarkably, the concentrations likely reached in body after the consumption of a standard pasta meal (usually 80 gr) are in the range of the lowest tested $\left(2 \times 10^{-5}-2 \times 10^{-4} \mu \mathrm{M},[70,71]\right)$, which provided a weak enhancement of the viability on both cell lines. On the other hand, at higher concentrations above $0.2 \mu \mathrm{M}$, which can be obtained only pharmacologically, caffeic acid showed a significant improvement of the cell viability, while indoleacetic acid and $\beta$-carotene showed comparable effects along the increase of concentration $(2-20 \mu \mathrm{M})$ in HEK-293 cells along the time.

\subsection{Effect of Indole-3-Acetic Acid, $\beta$-Carotene and Caffeic Acid on MMPP-Treated Cells}

We next wondered if indoleacetic acid, $\beta$-carotene and caffeic acid can counteract a stress induced by the oxidizing agent MMPP. First, we tested the MMPP effect by exposing HEK-293 and MDCK cells to serial dilutions $(0.005-0.05 \mathrm{mg} / \mathrm{mL})$ to the drug and the cell viability was determined. A dose-dependent decrease following MMPP treatment was noticed and the IC50 was comparable in the two cell lines tested. After incubation with $20-25 \mu \mathrm{g} / \mathrm{mL}$ MMPP the cell viability was significantly decreased to around $50-60 \%$ (Figure 4 ) and the half maximal inhibitory concentration $\left(\mathrm{IC}_{50}\right)$ was calculated to be $26 \mu \mathrm{g} / \mathrm{mL}$ for HEK-293 and $22 \mu \mathrm{g} / \mathrm{mL}$ for MDCK.
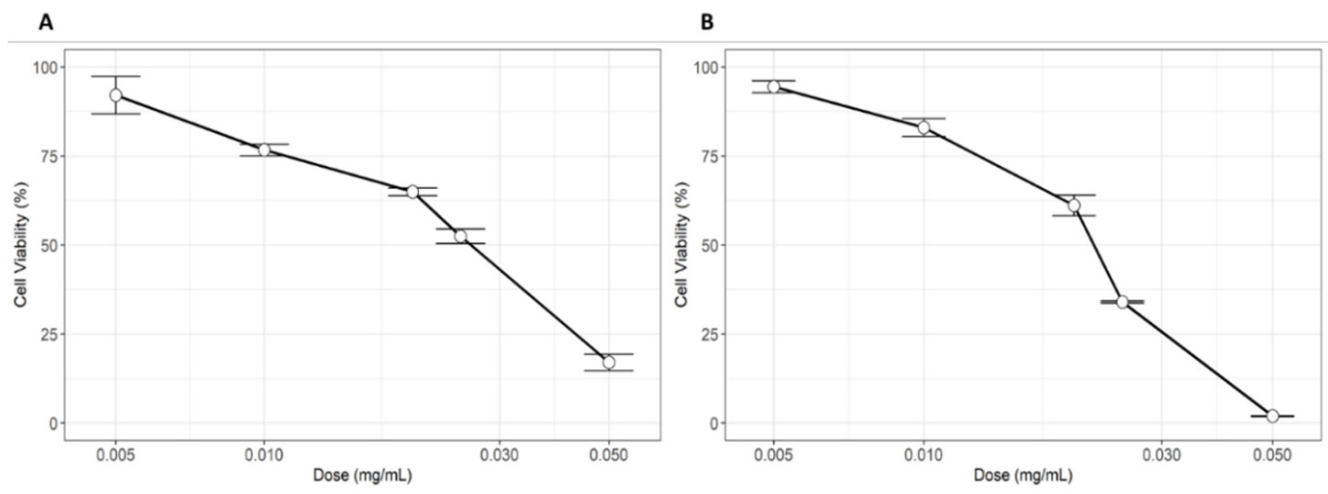

Figure 4. Effect of magnesium monoperoxyphtalate (MMPP) on cell viability of HEK-293 (A) and MDCK (B) after 24 (B) or 72 (A) hours incubation.

Then, we tested the protective activity of our anti-oxidant molecules on MMPPtreated cells, by supplementing the cell media with $2 \times 10^{-5} \mathrm{nM}$ indoleacetic, $\beta$-carotene or caffeic acid. A slightly positive effect on cell viability of both HEK-293 and MDCK was confirmed by employing the standards as such at the dose likely derived from a pasta portion (Figure 5).

As expected, MMPP reduced the call viability to $60-65 \%$; the treatment with indoleacetic acid or $\beta$-carotene counteract the MMPP effect and rescued the cell viability by $30 \%(p<0.001)$ and $27 \%(p>0.01)$ respectively on HEK-293 cells, while caffeic acid did not exert any significant effect. In the presence of an oxidant agent, beta-carotene and indoleacetic acid showed a protective effect on the cells at a low concentration, whereas caffeic acid did not counteract oxidative stress at the concentration needed to enhance cell viability. Those positive effects are likely due to the antioxidant properties of indoleacetic acid and carotenoids that can significantly counterbalance the MMPP-mediated cytotoxicity at the dose used in this experimental condition. Nevertheless, no significant rescue was observed on MMPP-treated MDCK cells, suggesting that, even of standards alone displayed a significantly positive effect on cell viability, they are not sufficient to tackle the MMPP-induced oxidative stress. Embryonal HEK-293 cells seem to be more prompt to arrange a defense line against stress than adult MDCK, presumably due to additional cellular redox homeostasis systems. 

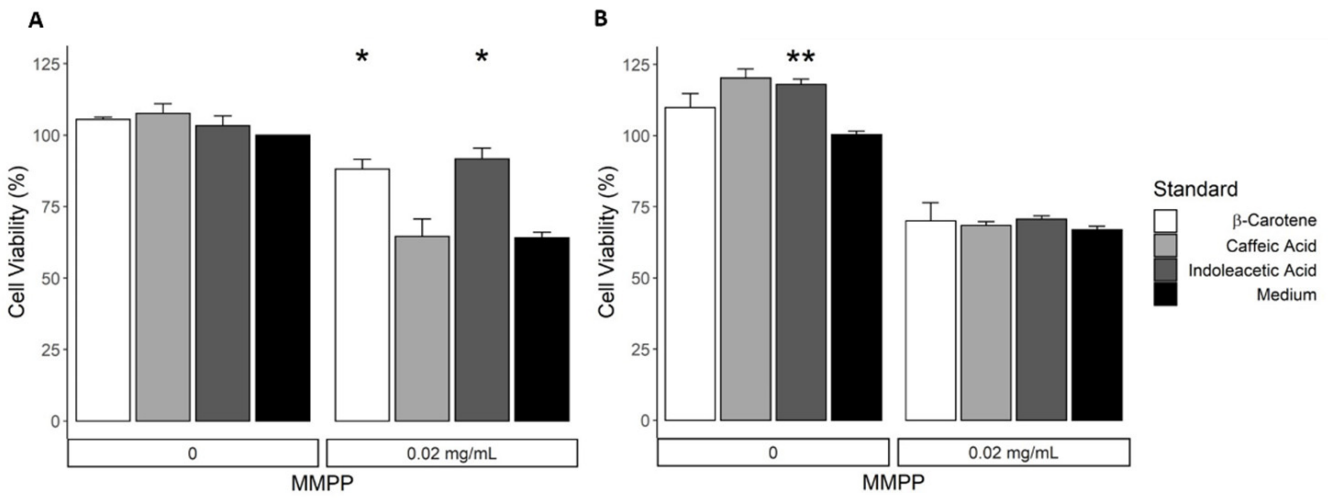

Figure 5. Effect of indoleacetic acid, $\beta$-carotene and caffeic acid on the cell viability of HEK-293 (A) and MDCK (B) in the absence or presence of MMPP after 24 (B) or 72 (A) hours incubation. Reported values correspond to mean of cell viability with standard error over three biological replicates. The percentage of cell viability was calculated using the ratio $\mathrm{Abs}_{\mathrm{TEST}} / \mathrm{Abs}_{\mathrm{CTRL}} \cdot{ }^{*} p<0.05 ;{ }^{* *} p<0.01$.

\subsection{Effect of the Pasta-Derived Carotenoid-Enriched Fraction on MMPP-Induced Cytotoxicity}

To evaluate the effects of the carotenoid-enriched fractions derived from the acetone extraction of buckwheat pasta and egg pasta on renal cells in the presence of oxidative stress, HEK-293 cells were incubated with different concentrations of extracts ranking from $2 \times 10^{-6} \mu \mathrm{M}$ to $2 \times 10^{-3} \mu \mathrm{M}$ in presence of MMPP for $72 \mathrm{~h}$ (Figure 6 and Table S2). The concentration used refers to the of $\beta$-carotene concentration detected in the extract (Table 2). The lutein content ranged from $1.5 \times 10^{-6} \mu \mathrm{M}$ to $1.5 \times 10^{-3} \mu \mathrm{M}$ in Buckwheat pasta and from $1.34 \times 10^{-6} \mu \mathrm{M}$ to $1.34 \times 10^{-3} \mu \mathrm{M}$ in egg pasta.

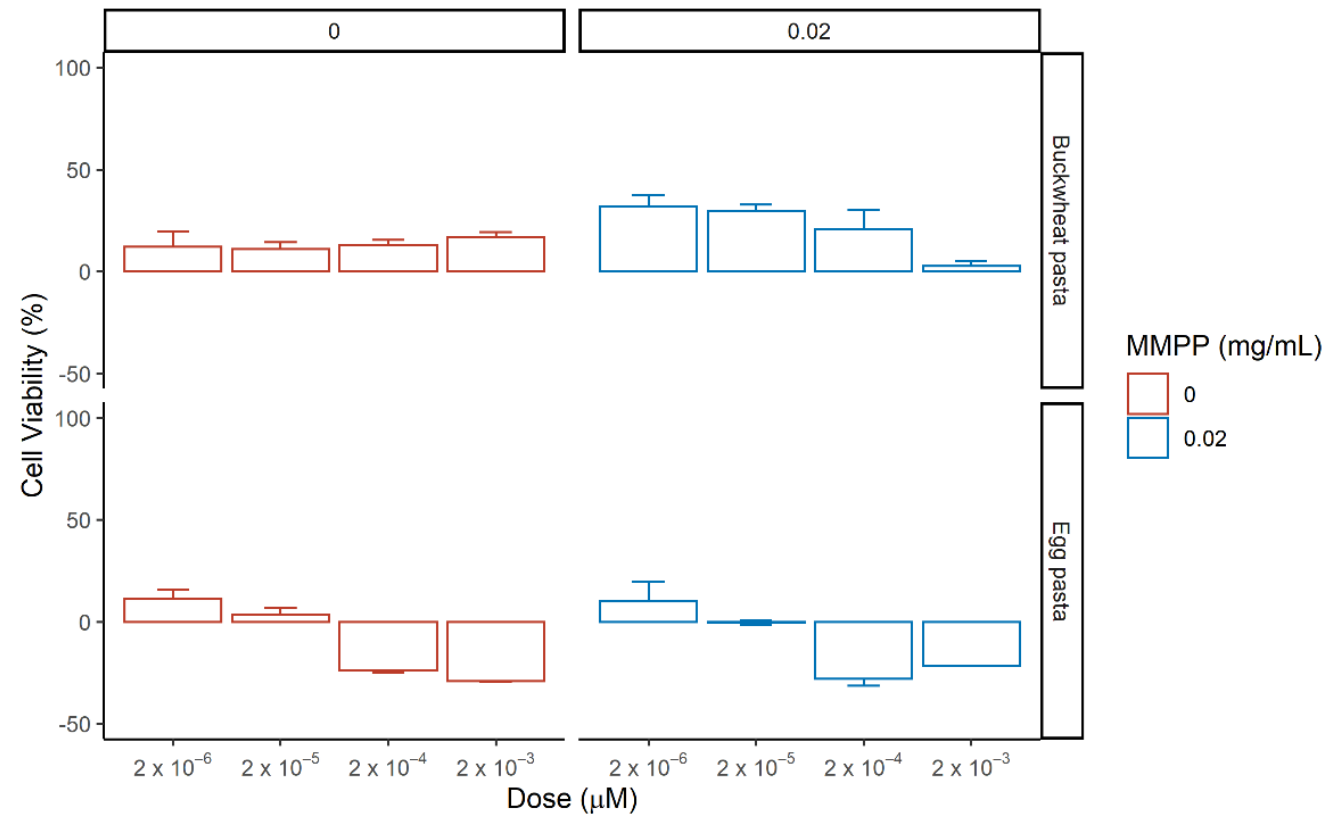

Figure 6. Effect of the pasta-derived carotenoid-enriched fractions on the cell viability of HEK-293 in the absence (left, red) or presence (right, blue) of MMPP after $72 \mathrm{~h}$ incubation. Reported values correspond to mean of the difference in cell viability between tested phytocomplexes and reference (medium in red, and MMPP in blue) with standard error over three biological replicates. The percentage of cell viability was calculated using the ratio $\mathrm{Abs}_{\mathrm{TEST}} / \mathrm{Abs}_{\mathrm{CTRL}}$.

In both acetone extracts, the presence of natural phytocomplexes, showed different effects with respect to the single standard, resulting more active at lower concentrations. As the concentration of extracts from egg pasta increases, a reduction of cell viability was 
observed. The lowest concentration of carotenoid extracts $\left(2 \times 10^{-6} \mu \mathrm{M}\right)$ induced a modest positive effect alone or in the presence of MMPP on HEK-293 cells. Buckwheat pasta extract generated an enhancement of cell viability as the extract alone, but also in the presence of MMPP ranging from $32 \pm 5 \%$ at lowest concentration to $21 \pm 9 \%$ for $2 \times 10^{-4} \mu \mathrm{M}$.

The activity of acetone extracts was assessed also on MDCK cells in presence or absence of MMPP and compared with that obtained in HEK-293 cells (Figure 7 and Table S2).

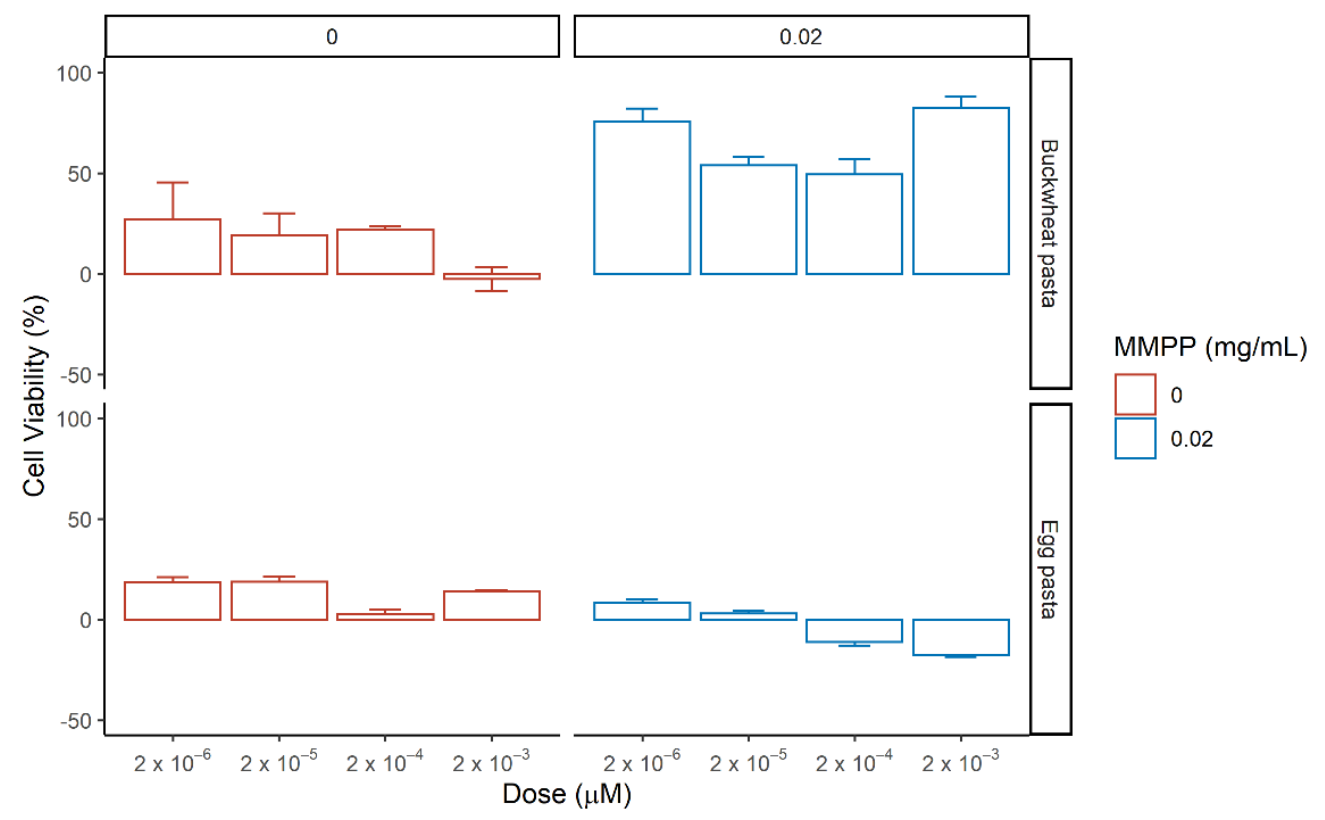

Figure 7. Effect of the pasta-derived carotenoid-enriched fractions on the cell viability of MadinDarby canine kidney (MDCK) in the absence (left, red) or presence (right, blue) of MMPP after $24 \mathrm{~h}$ incubation. Reported values correspond to mean of the difference in cell viability between tested phytocomplexes and reference (medium in red, and MMPP in blue) with standard error over three biological replicates. The percentage of cell viability was calculated using the ratio $\mathrm{Abs}_{\mathrm{TEST}} / \mathrm{Abs}_{\mathrm{CTRL}}$.

Carotenoids-enriched extracts gave an overall pro-viability effect at all the tested concentrations for both types of pasta. With respect to HEK-293 buckwheat pasta extract gave a better rescue upon MMPP treatment for all the doses ranging from $50 \pm 7 \%$ to $82 \pm 5 \%$ compared to HEK-239 cells; extracts from egg pasta exerted a small rescue only at the lowest concentration of carotenoids $2 \times 10^{-6} \mu \mathrm{M}$ in the presence of MMPP, suggesting that the specific composition of extracts plays a key role in the response. Thus, buckwheat pasta showed a greater rescue capacity on the cell viability with respect to egg pasta and since the experiments were performed using the same amount of $\beta$-carotene, the difference could be due to the presence of minor compounds, such as flavonoids compounds, higher in the former.

Carotenoids species are involved in different chemical reactions exerting a dual nature of oxidant and anti-oxidant depending the biological context and their concentrations: this high reactivity is due to the presence of the conjugated double bounds [72]. Their antioxidant role was associated with the ability to delocalize the electrons given by oxidative species and radicals $[73,74]$. In the presence of high oxidative conditions their activity may be converted to pro-oxidant [75]. In our cases, this finding was observed in egg pasta for HEK-293 (both alone and in presence of MMPP) and MDCK cells in presence of MMPP, where different doses of acetone extract produced opposite effects.

\subsection{Effect of Hydroalcoholic Extract on MMPP-Induced Cytotoxicity}

Afterwards, we evaluated the effects of the hydroalcoholic extracts from of buckwheat pasta, rye pasta and egg pasta on renal cells by testing different concentrations ranking from 
$5 \times 10^{-5} \mu \mathrm{M}$ to $5 \times 10^{-1} \mu \mathrm{M}$ with or without MMPP (Figure 8 and Table S3). The concentration used refers to the concentration of total phenolic content detected in the extract (Table 3). According to the content of the pasta samples reported in Table 1, for Buckwheat pasta the concentration of Indoleacetic acid was ranking from $1.85 \times 10^{-5} \mu \mathrm{M}$ to $1.85 \times 10^{-1} \mu \mathrm{M}$, for caffeic acid derivates was ranking from $3.5 \times 10^{-6} \mu \mathrm{M}$ to $3.5 \times 10^{-2} \mu \mathrm{M}$ and for flavonoids content was ranking from $2.8 \times 10^{-5} \mu \mathrm{M}$ to $2.8 \times 10^{-1} \mu \mathrm{M}$; for rye pasta the concentration of Indoleacetic acid was ranking from $2.2 \times 10^{-5} \mu \mathrm{M}$ to $2.2 \times 10^{-1} \mu \mathrm{M}$, for caffeic acid derivates from $1.95 \times 10^{-5} \mu \mathrm{M}$ to $1.95 \times 10^{-1} \mu \mathrm{M}$ and for flavonoids species from $8.5 \times 10^{-6} \mu \mathrm{M}$ to $8.5 \times 10^{-2} \mu \mathrm{M}$; for egg pasta the concentration of Indoleacetic acid was ranking from $4.25 \times 10^{-5} \mu \mathrm{M}$ to $4.25 \times 10^{-1} \mu \mathrm{M}$, for flavonoids species from $7.5 \times 10^{-6} \mu \mathrm{M}$ to $1.85 \times 10^{-2} \mu \mathrm{M}$ while no caffeic acid derivatives were present.

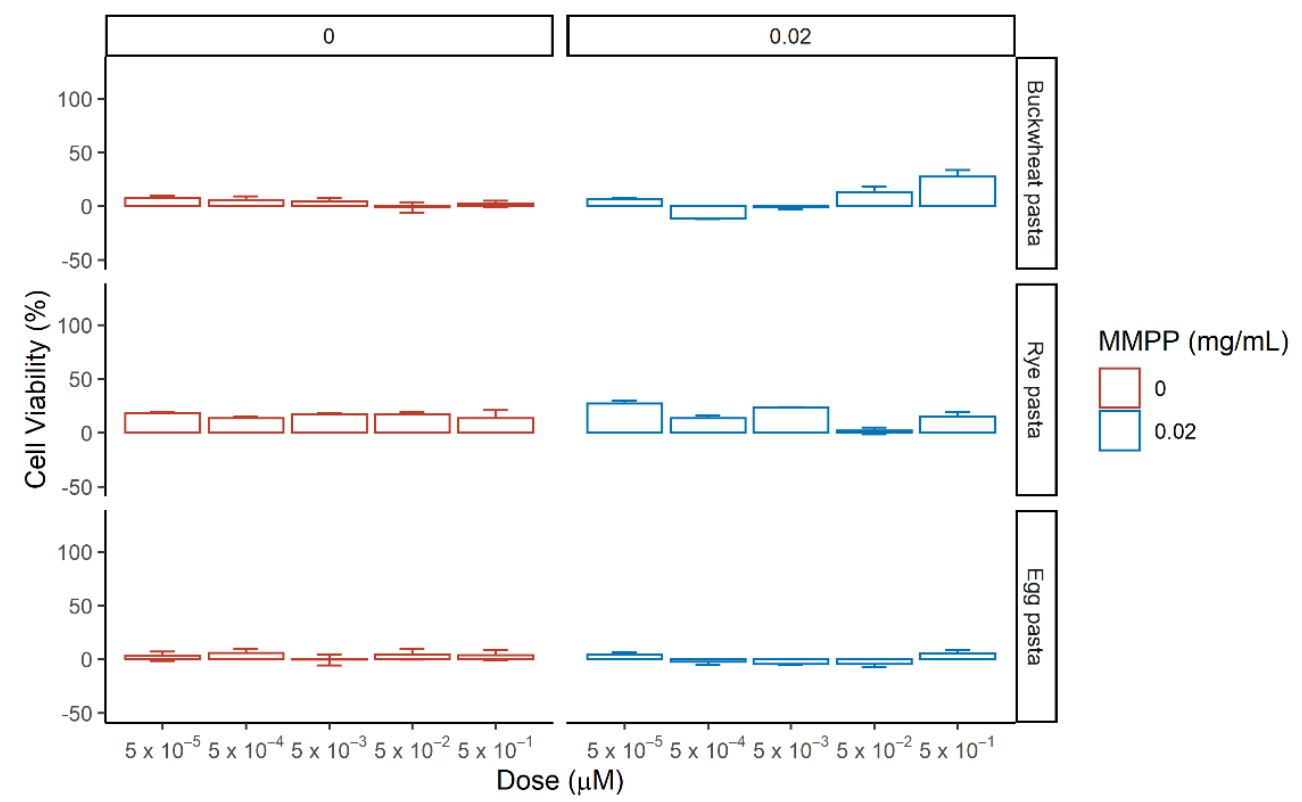

Figure 8. Effect of the pasta-derived hydroalcoholic extracts on the cell viability of HEK-293 in the absence (left, red) or presence (right, blue) of MMPP after $72 \mathrm{~h}$ incubation. Reported values correspond to mean of the difference in cell viability between tested phytocomplexes and reference (medium in red, and MMPP in blue) with standard error over three biological replicates. The percentage of cell viability was calculated using the ratio $\mathrm{Abs}_{\mathrm{TEST}} / \mathrm{Abs}_{\mathrm{CTRL}}$.

Hydroalcoholic extract from egg pasta did not exert any significant effect on HEK293 viability independently on the presence of oxidative stress. Extract from buckwheat pasta showed an enhancement of cell viability upon MMPP treatment only at the highest concentration $(28 \pm 6 \%)$. Rye pasta extract alone showed a general enhancement of the cell viability for all the doses ranging from $14 \pm 7 \%$ to $18 \pm 1 \%$ as well as in the presence of MMPP from $27 \pm 3 \%$ to $13 \pm 3 \%$. The phytocomplex presented in the extracts, resulted to be more active than single standards, exerting an effect on cell viability at lower concentrations compared to the latter. These results suggest that in the hydroalcoholic extracts, the major role in the rescue could be attributed to the presence of caffeic acid derivatives, observing higher rescue for rye pasta and lower/negligible effect for egg past, in which they are not detectable.

The hydroalcoholic extract were then tested on MDCK cells in the same conditions as before and the cell viability was assessed (Figure 9 and Table S4).

The hydroalcoholic extract from buckwheat and egg pasta displayed contrasting effects on cell viability: the first increases it, while the latter reduces it; no effect upon MMPP treatment was detected for both. Extract from rye pasta alone did not show any notable effect on cells viability, but it reveals a strong protective effect against MMPP- 
mediated oxidative stress at all the concentrations ranging from $50 \pm 7 \%$ to $61 \pm 21 \%$. In standard conditions.

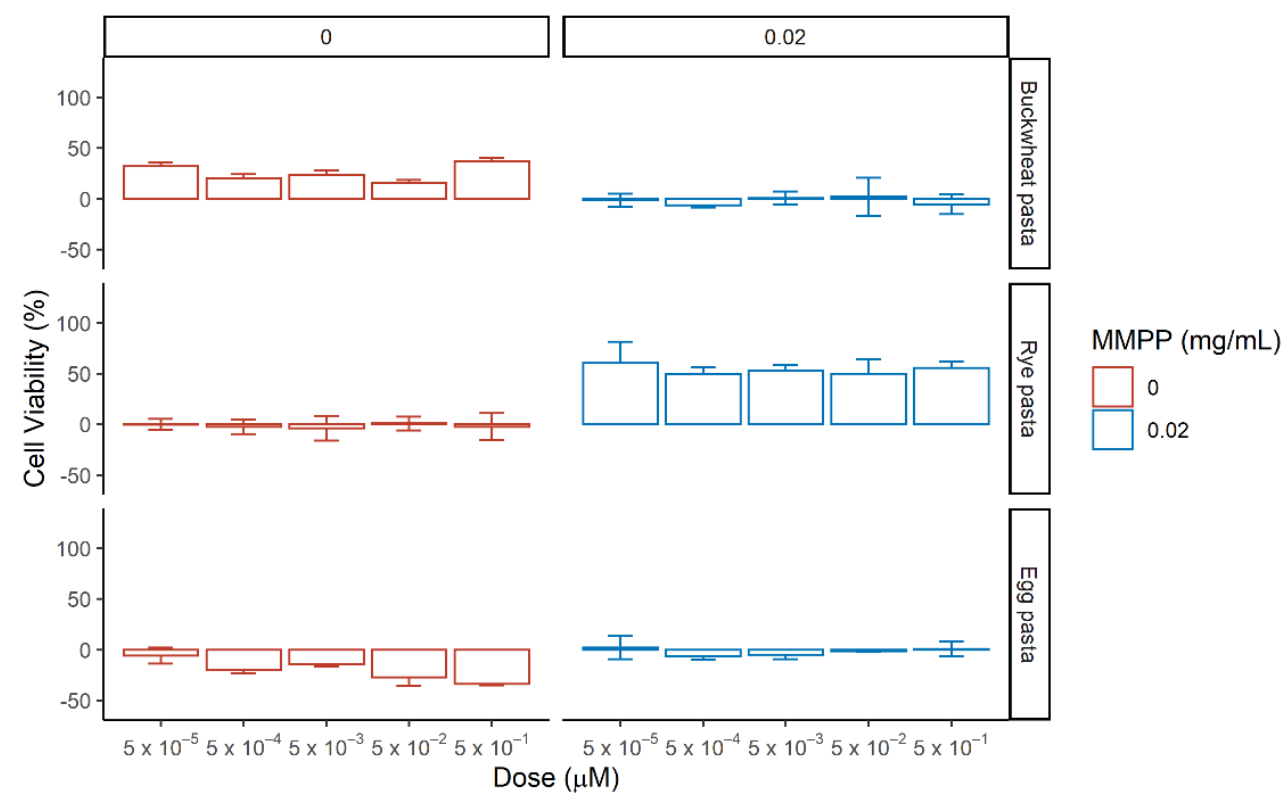

Figure 9. Effect of the pasta-derived hydroalcoholic extracts on the cell viability of MDCK in the absence (left, red) or presence (right, blue) of MMPP after $24 \mathrm{~h}$ incubation. Reported values correspond to mean of the difference in cell viability between tested phytocomplexes and reference (medium in red, and MMPP in blue) with standard error over three biological replicates. The percentage of cell viability was calculated using the ratio $\mathrm{Abs}_{\mathrm{TEST}} / \mathrm{Abs}_{\mathrm{CTRL}}$.

In the absence of MMPP, the high content of indoleacetic acid in the extract from egg pasta seems to exert a toxic effect on cell viability. Comparing the two cells models, we observed different behaviors with respect to the buckwheat and rye pasta in the absence of MMPP. In particular, HEK-293 showed an increase of viability with the latter, while MDCK with the former. The differences are related to the action of the phytocomplexes which are characterized by a higher content of flavonoids for the buckwheat pasta. The rescue on cell viability among samples, as observed for both cell lines, corresponds to the increase content of caffeic acid derivatives in rye pasta.

The study of the interaction between polyphenols containing phytocomplexes and renal cells, could help to investigate the known important effects on renal physiology exerted by those compounds [76], focusing on one of possible vehicle, pasta, typically associated with renal healthy diet. As a general rule, the metabolites of polyphenols have a plasma half-life of a few hours and are rapidly eliminated by the kidney and by the liver: the urinary and the biliary excretion route. The total amount of polyphenol metabolites excreted in urine is correlated not only with their maximum plasma concentration but also with their ability to be excreted by biliary rather than urinary tract. For example, urinary excretion of quercetin and its glycosides accounts for $0.3-1.4 \%$ of the ingested dose [77]; for caffeic acid and for ferulic acids accounts for $5.9 \%$ and $27 \%$ respectively. Therefore, pasta-derived polyphenols can have a positive impact on renal cells depending on their amount and metabolism. Further studies are needed to better define their contribution to kidney health.

\section{Conclusions}

The consumption of pasta is nowadays so diffused and accessible that this food could be one of the most common carriers for important metabolites, such as carotenoids and polyphenols that have been associated to general health and to protective mechanisms for kidney. In this study, we assessed the positive effects of bioactive compounds by comparing 
different type of pasta, highlighting how it represents an unconventional source of them. The comparison of the different cell responses between single molecules and extracts suggests considering the exerted activity as derived from the whole phytocomplex whit the presence of carotenoids such as lutein and polyphenols such as indoleacetic acid, respect to the individual species and the consequential attention to the raw materials. The scope of this study was (1) to strengthen the role of pasta as a food for the promotion of renal health in the healthy population and (2) for it to be a starting point for the improvement of the micronutrient profile in aproteic pastas. The results of this study suggest that the antioxidant species present in pasta play a major role in the protection of kidney cells from oxidative stress and reinforces the healthy role of quality organic pasta in the Mediterranean diet. High oxidative stress characterizes CKD and an anti-oxidant compounds can be beneficial to counteract it.

Even though the WHO and the FDA consider pasta as the most adequate food for fortification, in agreement with the very definition of fortified food (which is supplementing food with what is deficient in the population), we believe that pasta fortification is necessary only for special medical purpose, including protein-free pasta for CKD patients. For these patients, the micronutrient deficit in protein-free food and the necessary dietary restrictions to which they are subjected could generate nutritional deficiencies. In all the other cases, pasta fortification may not be necessary since pasta is naturally rich in complex carbohydrates and protein and low in fat and is therefore an already highly nutritious food by itself, especially if it is whole wheat based. Our study was meant to be an explorative preliminary study aimed at evaluating the possible beneficial effect that the polyphenolic components present in pasta could elicit on renal cells.

Supplementary Materials: The following are available online at https:/ / www.mdpi.com/article / 10.3390/nu13041131/s1, Table S1: Nutritional Table. Table S2-Detection of cell viability variation of HEK-293 and MDCK incubated with increasing amount of carotenoid-enriched fraction from Buckwheat pasta and Egg pasta on medium and MMPP for 72 (HEK-293) and 24 (MDCK) hours. ${ }^{*} p<0.5,{ }^{* *} p<0.01,{ }^{* * *} p<0.001$. Table S3-Detection of cell viability variation of HEK-293 incubated with increasing amount of hydroalcoholic extract from Buckwheat pasta, Rye pasta and Egg pasta on medium and MMPP for $72 \mathrm{~h}$. ${ }^{*} p<0.5,{ }^{* *} p<0.01,{ }^{* * *} p<0.001$. Table S4-Detection of cell viability variation of MDCK incubated with increasing amount of hydroalcoholic extract from Buckwheat pasta, Rye pasta and Egg pasta on medium and MMPP for $24 \mathrm{~h}$. ${ }^{*} p<0.5{ }^{* *} p<0.01,{ }^{* * *} p<0.001$. Figure S1: MS spectra of Kaempferol in Buckwheat cooked pasta hydroalcoholic extract. Figure S2: MS spectra of quercetin in Buckwheat cooked pasta hydroalcoholic extract. Figure S3: MS spectra of rutin in cooked pasta hydroalcoholic extract. Figure S4: MS spectra of ferulic acid one in rye cooked pasta hydroalcoholic extract. Figure S5: MS spectra of apigenin diglicosides in egg cooked pasta hydroalcoholic extract. Figure S6: Detection cell viability of HEK-293 incubated with increasing amount of Indoleacetic acid, $\beta$-carotene and caffeic acid for 24 (A) and 48 (B) hours Reported values correspond to mean of cell viability with standard error over three biological replicates. The percentage of cell viability was calculated using the ratio $\mathrm{Abs}_{\mathrm{TEST}} / \mathrm{Abs}_{\mathrm{CTRL}}$.

Author Contributions: Conceptualization, A.R., R.V. and A.B.; methodology, F.D.M., P.V., A.R. and A.B.; software, F.D.M.; formal analysis, F.D.M.; investigation, R.V. and A.B.; resources, A.R., R.V. and A.B.; data curation, F.D.M.; writing-original draft preparation, F.D.M., S.U., R.V. and A.B.; writing-review and editing, F.T., S.U., P.V., A.S., F.M. and A.R.; visualization, F.D.M. and R.V.; supervision, A.R., R.V. and A.B.; project administration, A.R., R.V. and A.B.; funding acquisition, F.T., A.R., R.V. and A.B. All authors have read and agreed to the published version of the manuscript.

Funding: This work was supported by funds from the RE.ME.DIET. project.

Conflicts of Interest: The authors declare no conflict of interest.

\section{References}

1. Lăcătușu, C.M.; Grigorescu, E.D.; Floria, M.; Onofriescu, A.; Mihai, B.M. The mediterranean diet: From an environment-driven food culture to an emerging medical prescription. Int. J. Environ. Res. Public Health 2019, 16, 942. [CrossRef]

2. Jacobs, D.R.; Gross, M.D.; Tapsell, L.C. Food synergy: An operational concept for understanding nutrition. Am. J. Clin. Nutr. 2009, 89, 1543S. [CrossRef] [PubMed] 
3. De Lorgeril, M.; Salen, P.; Martin, J.-L.; Monjaud, I.; Delaye, J.; Mamelle, N. Mediterranean Diet, Traditional Risk Factors, and the Rate of Cardiovascular Complications After Myocardial Infarction. Circulation 1999, 99, 779-785. [CrossRef]

4. Psaltopoulou, T.; Naska, A.; Orfanos, P.; Trichopoulos, D.; Mountokalakis, T.; Trichopoulou, A. Olive oil, the Mediterranean diet, and arterial blood pressure: The Greek European Prospective Investigation into Cancer and Nutrition (EPIC) study. Am. J. Clin. Nutr. 2004, 80, 1012-1018. [CrossRef]

5. $\quad$ Estruch, R.; Ros, E.; Salas-Salvadó, J.; Covas, M.-I.; Corella, D.; Arós, F.; Gómez-Gracia, E.; Ruiz-Gutiérrez, V.; Fiol, M.; Lapetra, J.; et al. Primary prevention of cardiovascular disease with a mediterranean diet. Z. Gefassmedizin 2013, 10, 28. [CrossRef] [PubMed]

6. Uusitupa, M.; Khan, T.A.; Viguiliouk, E.; Kahleova, H.; Rivellese, A.A.; Hermansen, K.; Pfeiffer, A.; Thanopoulou, A.; SalasSalvadó, J.; Schwab, U.; et al. Prevention of type 2 diabetes by lifestyle changes: A systematic review and meta-analysis. Nutrients 2019, 11, 2611. [CrossRef] [PubMed]

7. Jannasch, F.; Kröger, J.; Schulze, M.B. Dietary patterns and Type 2 diabetes: A systematic literature review and meta-analysis of prospective studies. J. Nutr. 2017, 147, 1174-1182. [CrossRef]

8. Esposito, K.; Chiodini, P.; Maiorino, M.I.; Bellastella, G.; Panagiotakos, D.; Giugliano, D. Which diet for prevention of type 2 diabetes? A meta-analysis of prospective studies. Endocrine 2014, 47, 107-116. [CrossRef] [PubMed]

9. Huo, R.; Du, T.; Xu, Y.; Xu, W.; Chen, X.; Sun, K.; Yu, X. Effects of Mediterranean-style diet on glycemic control, weight loss and cardiovascular risk factors among type 2 diabetes individuals: A meta-analysis. Eur. J. Clin. Nutr. 2015, 69, 1200-1208. [CrossRef] [PubMed]

10. Martín-Peláez, S.; Fito, M.; Castaner, O. Mediterranean diet effects on type 2 diabetes prevention, disease progression, and related mechanisms. A review. Nutrients 2020, 12, 2236. [CrossRef] [PubMed]

11. Milajerdi, A.; Namazi, N.; Larijani, B.; Azadbakht, L. The Association of Dietary Quality Indices and Cancer Mortality: A Systematic Review and Meta-analysis of Cohort Studies. Nutr. Cancer 2018, 70, 1091-1105. [CrossRef] [PubMed]

12. Schwingshackl, L.; Schwedhelm, C.; Galbete, C.; Hoffmann, G. Adherence to mediterranean diet and risk of cancer: An updated systematic review and meta-analysis. Nutrients 2017, 9, 1063. [CrossRef]

13. Sayón-Orea, C.; Razquin, C.; Bulló, M.; Corella, D.; Fitó, M.; Romaguera, D.; Vioque, J.; Alonso-Gómez, Á.M.; Wärnberg, J.; Martínez, J.A.; et al. Effect of a Nutritional and Behavioral Intervention on Energy-Reduced Mediterranean Diet Adherence among Patients with Metabolic Syndrome: Interim Analysis of the PREDIMED-Plus Randomized Clinical Trial. JAMA J. Am. Med. Assoc. 2019, 322, 1486-1499. [CrossRef] [PubMed]

14. Bajerska, J.; Chmurzynska, A.; Muzsik, A.; Krzyżanowska, P.; Mądry, E.; Malinowska, A.M.; Walkowiak, J. Weight loss and metabolic health effects from energy-restricted Mediterranean and Central-European diets in postmenopausal women: A randomized controlled trial. Sci. Rep. 2018, 8, 11170. [CrossRef]

15. Estruch, R.; Martínez-González, M.A.; Corella, D.; Salas-Salvadó, J.; Fitó, M.; Chiva-Blanch, G.; Fiol, M.; Gómez-Gracia, E.; Arós, F.; Lapetra, J.; et al. Effect of a high-fat Mediterranean diet on bodyweight and waist circumference: A prespecified secondary outcomes analysis of the PREDIMED randomised controlled trial. Lancet Diabetes Endocrinol. 2019, 7, e6-e17. [CrossRef]

16. Molendijk, M.; Molero, P.; Ortuño Sánchez-Pedreño, F.; Van der Does, W.; Angel Martínez-González, M. Diet quality and depression risk: A systematic review and dose-response meta-analysis of prospective studies. J. Affect. Disord. 2018, 226, 346-354. [CrossRef]

17. $\mathrm{Wu}, \mathrm{L}$.; Sun, D. Adherence to Mediterranean diet and risk of developing cognitive disorders: An updated systematic review and meta-analysis of prospective cohort studies. Sci. Rep. 2017, 7, 1-9. [CrossRef]

18. Loughrey, D.G.; Lavecchia, S.; Brennan, S.; Lawlor, B.A.; Kelly, M.E. The impact of the mediterranean diet on the cognitive functioning of healthy older adults: A systematic review and meta-analysis. Adv. Nutr. 2017, 8, 571-586.

19. Arnold, S.E.; Arvanitakis, Z.; Macauley-Rambach, S.L.; Koenig, A.M.; Wang, H.Y.; Ahima, R.S.; Craft, S.; Gandy, S.; Buettner, C.; Stoeckel, L.E.; et al. Brain insulin resistance in type 2 diabetes and Alzheimer disease: Concepts and conundrums. Nat. Rev. Neurol. 2018, 14, 168-181. [CrossRef]

20. Trichopoulou, A.; Vasilopoulou, E. Mediterranean diet and longevity. Br. J. Nutr. 2020, 84, S205-S209. [CrossRef]

21. Toledo, E.; Hu, F.B.; Estruch, R.; Buil-Cosiales, P.; Corella, D.; Salas-Salvadó, J.; Covas, M.I.; Arós, F.; Gómez-Gracia, E.; Fiol, M.; et al. Effect of the Mediterranean diet on blood pressure in the PREDIMED trial: Results from a randomized controlled trial. $B M C$ Med. 2013, 11, 207. [CrossRef] [PubMed]

22. Solá, R.; Fitó, M.; Estruch, R.; Salas-Salvadó, J.; Corella, D.; de La Torre, R.; Muñoz, M.A.; del Carmen López-Sabater, M.; Martínez-González, M.A.; Arós, F.; et al. Effect of a traditional Mediterranean diet on apolipoproteins B, A-I, and their ratio: A randomized, controlled trial. Atherosclerosis 2011, 218, 174-180. [CrossRef] [PubMed]

23. Hernáez, Á.; Castañer, O.; Elosua, R.; Pintó, X.; Estruch, R.; Salas-Salvadó, J.; Corella, D.; Arós, F.; Serra-Majem, L.; Fiol, M.; et al. Mediterranean Diet Improves High-Density Lipoprotein Function in High-Cardiovascular-Risk Individuals. Circulation 2017, 135, 633-643. [CrossRef]

24. Mirabelli, M.; Chiefari, E.; Arcidiacono, B.; Corigliano, D.M.; Brunetti, F.S.; Maggisano, V.; Russo, D.; Foti, D.P.; Brunetti, A. Mediterranean Diet Nutrients to Turn the Tide against Insulin Resistance and Related Diseases. Nutrients 2020, 12, 1066. [CrossRef]

25. Fitó, M.; Guxens, M.; Corella, D.; Sáez, G.; Estruch, R.; De La Torre, R.; Francés, F.; Cabezas, C.; López-Sabater, M.D.C.; Marrugat, J.; et al. Effect of a traditional Mediterranean diet on lipoprotein oxidation: A randomized controlled trial. Arch. Intern. Med. 2007, 167, 1195-1203. [CrossRef] 
26. Calder, P.C.; Ahluwalia, N.; Brouns, F.; Buetler, T.; Clement, K.; Cunningham, K.; Esposito, K.; Jönsson, L.S.; Kolb, H.; Lansink, M.; et al. Dietary factors and low-grade inflammation in relation to overweight and obesity. Br. J. Nutr. 2011, 106, S1-S78. [CrossRef]

27. Torres-Peña, J.D.; Rangel-Zuñiga, O.A.; Alcala-Diaz, J.F.; Lopez-Miranda, J.; Delgado-Lista, J. Mediterranean Diet and Endothelial Function: A Review of its Effects at Different Vascular Bed Levels. Nutrients 2020, 12, 2212. [CrossRef]

28. Marin, C.; Ramirez, R.; Delgado-Lista, J.; Yubero-Serrano, E.M.; Perez-Martinez, P.; Carracedo, J.; Garcia-Rios, A.; Rodriguez, F.; Gutierrez-Mariscal, F.M.; Gomez, P.; et al. Mediterranean diet reduces endothelial damage and improves the regenerative capacity of endothelium. Am. J. Clin. Nutr. 2011, 93, 267-274. [CrossRef]

29. Huang, X.; Jiménez-Molén, J.J.; Lindholm, B.; Cederholm, T.; Ärnlöv, J.; Risérus, U.; Sjögren, P.; Carrero, J.J. Mediterranean diet, kidney function, and mortality in men with CKD. Clin. J. Am. Soc. Nephrol. 2013, 8, 1548-1555. [CrossRef] [PubMed]

30. Bach, K.E.; Kelly, J.T.; Campbell, K.L.; Palmer, S.C.; Khalesi, S.; Strippoli, G.F.M. Healthy dietary patterns and incidence of CKD: A meta-analysis of cohort studies. Clin. J. Am. Soc. Nephrol. 2019, 14, 1441-1449. [CrossRef] [PubMed]

31. Monsalve, B.; Concha-Meyer, A.; Palomo, I.; Fuentes, E. Mechanisms of endothelial protection by natural bioactive compounds from fruit and vegetables. An. Acad. Bras. Cienc. 2017, 89, 615-633. [CrossRef] [PubMed]

32. Zoccali, C. Endothelial dysfunction and the kidney: Emerging risk factors for renal insufficiency and cardiovascular outcomes in essential hypertension. J. Am. Soc. Nephrol. 2006, 17, 61-63. [CrossRef] [PubMed]

33. Galle, J.; Quaschning, T.; Seibold, S.; Wanner, C. Endothelial dysfunction and inflammation: What is the link? Kidney Int. Suppl. 2003, 63, 45-49. [CrossRef] [PubMed]

34. Kontessis, P.S.; Bossinakou, I.; Sarika, L.; Iliopoulou, E.; Papantoniou, A.; Trevisan, R.; Roussi, D.; Stipsanelli, K.; Grigorakis, S.; Souvatzoglou, A. Renal, metabolic, and hormonal responses to proteins of different origin in normotensive, nonproteinuric type I diabetic patients. Diabetes Care 1995, 18, 1233-1240. [CrossRef] [PubMed]

35. Metges, C.C.; Barth, C.A. Metabolic consequences of a high dietary-protein intake in adulthood: Assessment of the available evidence. J. Nutr. 2000, 130, 886-889. [CrossRef]

36. Epstein, F.H.; Brenner, B.M.; Meyer, T.W.; Hostetter, T.H. Dietary Protein Intake and the Progressive Nature of Kidney Disease. N. Engl. J. Med. 1982, 307, 652-659. [CrossRef]

37. Knight, E.L.; Stampfer, M.J.; Hankinson, S.E.; Spiegelman, D.; Curhan, G.C. The Impact of Protein Intake on Renal Function Decline in Women with Normal Renal Function or Mild Renal Insufficiency. Ann. Intern. Med. 2003, 138. [CrossRef] [PubMed]

38. Halbesma, N.; Bakker, S.J.L.; Jansen, D.F.; Stolk, R.P.; De Zeeuw, D.; De Jong, P.E.; Gansevoort, R.T. High protein intake associates with cardiovascular events but not with loss of renal function. J. Am. Soc. Nephrol. 2009, 20, 1797-1804. [CrossRef]

39. Cirillo, M.; Lombardi, C.; Chiricone, D.; De Santo, N.G.; Zanchetti, A.; Bilancio, G. Protein intake and kidney function in the middle-age population: Contrast between cross-sectional and longitudinal data. Nephrol. Dial. Transplant. 2014, 29, 1733-1740. [CrossRef]

40. Lew, Q.L.J.; Jafar, T.H.; Koh, H.W.L.; Jin, A.; Chow, K.Y.; Yuan, J.M.; Koh, W.P. Red meat intake and risk of ESRD. J. Am. Soc. Nephrol. 2017, 28, 304-312. [CrossRef]

41. Lin, J.; Fung, T.T.; Hu, F.B.; Curhan, G.C. Association of dietary patterns with albuminuria and kidney function decline in older white women: A subgroup analysis from the nurses health study. Am. J. Kidney Dis. 2011, 57, 245-254. [CrossRef]

42. Azadbakht, L.; Atabak, S.; Esmaillzadeh, A. Soy protein intake, cardiorenal indices, and C-reactive protein in type 2 diabetes with nephropathy. Diabetes Care 2008, 31, 648-654. [CrossRef]

43. Cai, Q.; Dekker, L.H.; Bakker, S.J.L.; de Borst, M.H.; Navis, G.J. Dietary Patterns Based on Estimated Glomerular Filtration Rate and Kidney Function Decline in the General Population: The Lifelines Cohort Study. Nutrients 2020, 12, 1099. [CrossRef] [PubMed]

44. Nilusha, R.A.T.; Jayasinghe, J.M.J.K.; Perera, O.D.A.N.; Perera, P.I.P. Development of pasta products with nonconventional ingredients and their effect on selected quality characteristics: A brief overview. Int. J. Food Sci. 2019, 2019, 6750726. [CrossRef] [PubMed]

45. Holasova, M.; Fiedlerova, V.; Smrcinova, H.; Orsak, M.; Lachman, J.; Vavreinova, S. Buckwheat-The source of antioxidant activity in functional foods. Food Res. Int. 2002, 35, 207-211. [CrossRef]

46. Velioglu, Y.S.; Mazza, G.; Gao, L.; Oomah, B.D. Antioxidant Activity and Total Phenolics in Selected Fruits, Vegetables, and Grain Products. J. Agric. Food Chem. 1998, 46, 4113-4117. [CrossRef]

47. Pounis, G.; Di Castelnuovo, A.; Costanzo, S.; Persichillo, M.; Bonaccio, M.; Bonanni, A.; Cerletti, C.; Donati, M.B.; De Gaetano, G.; Iacoviello, L. Association of pasta consumption with body mass index and waist-to-hip ratio: Results from Moli-sani and INHES studies. Nutr. Diabetes 2016, 6, e218. [CrossRef]

48. Huang, M.; Li, J.; Ha, M.A.; Riccardi, G.; Liu, S. A systematic review on the relations between pasta consumption and cardiometabolic risk factors. Nutr. Metab. Cardiovasc. Dis. 2017, 27, 939-948. [CrossRef]

49. Sandberg, J.C.; Björck, I.M.E.; Nilsson, A.C. Rye-based evening meals favorably affected glucose regulation and appetite variables at the following breakfast; a randomized controlled study in healthy subjects. PLoS ONE 2016, 11, e0151985. [CrossRef]

50. Magnusdottir, O.K.; Landberg, R.; Gunnarsdottir, I.; Cloetens, L.; Åkesson, B.; Rosqvist, F.; Schwab, U.; Herzig, K.-H.; Hukkanen, J.; Savolainen, M.J.; et al. Whole Grain Rye Intake, Reflected by a Biomarker, Is Associated with Favorable Blood Lipid Outcomes in Subjects with the Metabolic Syndrome-A Randomized Study. PLoS ONE 2014, 9, e110827. [CrossRef]

51. Abdel-Aal, E.S.M.; Akhtar, H.; Zaheer, K.; Ali, R. Dietary sources of lutein and zeaxanthin carotenoids and their role in eye health. Nutrients 2013, 5, 1169-1185. [CrossRef] [PubMed] 
52. Bustos, M.C.; Perez, G.T.; Leon, A.E. Structure and quality of pasta enriched with functional ingredients. RSC Adv. 2015, 5, 30780-30792. [CrossRef]

53. Ciccoritti, R.; Taddei, F.; Nicoletti, I.; Gazza, L.; Corradini, D.; D’Egidio, M.G.; Martini, D. Use of bran fractions and debranned kernels for the development of pasta with high nutritional and healthy potential. Food Chem. 2017, 225, 77-86. [CrossRef] [PubMed]

54. Kiprovski, B.; Mikulic-Petkovsek, M.; Slatnar, A.; Veberic, R.; Stampar, F.; Malencic, D.; Latkovic, D. Comparison of phenolic profiles and antioxidant properties of European Fagopyrum esculentum cultivars. Food Chem. 2015, 185, 41-47. [CrossRef]

55. Cervantes-Paz, B.; Victoria-Campos, C.I.; Ornelas-Paz, J. de J. Absorption of carotenoids and mechanisms involved in their health-related properties. Subcell. Biochem. 2016, 79, 415-454. [CrossRef] [PubMed]

56. Maiani, G.; Castón, M.J.P.; Catasta, G.; Toti, E.; Cambrodón, I.G.; Bysted, A.; Granado-Lorencio, F.; Olmedilla-Alonso, B.; Knuthsen, P.; Valoti, M.; et al. Carotenoids: Actual knowledge on food sources, intakes, stability and bioavailability and their protective role in humans. Mol. Nutr. Food Res. 2009, 53, 194-218. [CrossRef] [PubMed]

57. Singleton, V.L.; Orthofer, R.; Lamuela-Raventós, R.M. Analysis of total phenols and other oxidation substrates and antioxidants by means of folin-ciocalteu reagent. Methods Enzymol. 1999, 299, 152-178. [CrossRef]

58. Dewanto, V.; Xianzhong, W.; Adom, K.K.; Liu, R.H. Thermal processing enhances the nutritional value of tomatoes by increasing total antioxidant activity. J. Agric. Food Chem. 2002, 50, 3010-3014. [CrossRef]

59. R Core Team. R: A Language and Environment for Statistical Computing; R Foundation for Statistical Computing: Vienna, Austria, 2019.

60. R Studio Team. RStudio: Integrated Development Environment for R; RStudio, PBC: Boston, MA, USA, 2019.

61. Wickham, H.; Averick, M.; Bryan, J.; Chang, W.; McGowan, L.D.; François, R.; Grolemund, G.; Hayes, A.; Henry, L.; Hester, J.; et al. Welcome to the tidyverse. J. Open Source Softw. 2019, 4, 1686. [CrossRef]

62. Gupta, A.; Sharma, S.; Reddy Surasani, V.K. Quinoa protein isolate supplemented pasta: Nutritional, physical, textural and morphological characterization. LWT 2021, 135, 110045. [CrossRef]

63. Vignolini, P.; Urciuoli, S.; Heimler, D.; Romani, A. Carotenoids, Polyphenols and Antioxidant Activity Evaluation in StoneGrinded Wheat Semolina. J. Health Sci. 2018, 6, 432-438. [CrossRef]

64. Salehi, A.; Fallah, S.; Kaul, H.P.; Zitterl-Eglseer, K. Antioxidant capacity and polyphenols in buckwheat seeds from fenugreek/buckwheat intercrops as influenced by fertilization. J. Cereal Sci. 2018, 84, 142-150. [CrossRef]

65. Francis Raguindin, P.; Adam Itodo, O.; Stoyanov, J.; Dejanovic, G.M.; Gamba, M.; Asllanaj, E.; Minder, B.; Bussler, W.; Metzger, B.; Muka, T.; et al. A systematic review of phytochemicals in oat and buckwheat. Food Chem. 2021, 338. [CrossRef] [PubMed]

66. Bondia-Pons, I.; Aura, A.M.; Vuorela, S.; Kolehmainen, M.; Mykkänen, H.; Poutanen, K. Rye phenolics in nutrition and health. J. Cereal Sci. 2009, 49, 323-336. [CrossRef]

67. Asenstorfer, R.E.; Wang, Y.; Mares, D.J. Chemical structure of flavonoid compounds in wheat (Triticum aestivum L.) flour that contribute to the yellow colour of Asian alkaline noodles. J. Cereal Sci. 2006, 43, 108-119. [CrossRef]

68. Mellado-Ortega, E.; Hornero-Méndez, D. Effect of long-term storage on the free and esterified carotenoids in durum wheat (Triticum turgidum conv. durum) and tritordeum ( $\times$ Tritordeum Ascherson et Graebner) grains. Food Res. Int. 2017, 99, 877-890. [CrossRef]

69. Gyurászová, M.; Gurecká, R.; Bábíčková, J.; Tóthová, L'. Oxidative Stress in the Pathophysiology of Kidney Disease: Implications for Noninvasive Monitoring and Identification of Biomarkers. Oxidative Med. Cell. Longev. 2020, 2020, 5478708. [CrossRef]

70. Haskell, M.J. The challenge to reach nutritional adequacy for vitamin A: $\beta$-carotene bioavailability and conversion-Evidence in humans. Am. J. Clin. Nutr. 2012, 96, 1193S-1203S. [CrossRef]

71. Olthof, M.R.; Hollman, P.C.H.; Katan, M.B. Chlorogenic acid and caffeic acid are absorbed in humans. J. Nutr. 2001, 131, 66-71. [CrossRef]

72. Ribeiro, D.; Freitas, M.; Silva, A.M.S.; Carvalho, F.; Fernandes, E. Antioxidant and pro-oxidant activities of carotenoids and their oxidation products. Food Chem. Toxicol. 2018, 120, 681-699. [CrossRef]

73. Jomova, K.; Valko, M. Health protective effects of carotenoids and their interactions with other biological antioxidants. Eur. J. Med. Chem. 2013, 70, 102-110. [CrossRef]

74. Rao, A.V.; Rao, L.G. Carotenoids and human health. Pharmacol. Res. 2007, 55, 207-216. [CrossRef] [PubMed]

75. Kikugawa, K.; Hiramoto, K.; Tomiyama, S.; Asano, Y. $\beta$-Carotene effectively scavenges toxic nitrogen oxides: Nitrogen dioxide and peroxynitrous acid. FEBS Lett. 1997, 404, 175-178. [CrossRef]

76. Mafra, D.; Borges, N.A.; Lindholm, B.; Shiels, P.G.; Evenepoel, P.; Stenvinkel, P. Food as medicine: Targeting the uraemic phenotype in chronic kidney disease. Nat. Rev. Nephrol. 2020, 17, 153-171. [CrossRef] [PubMed]

77. Graefe, E.U.; Wittig, J.; Mueller, S.; Riethling, A.K.; Uehleke, B.; Drewelow, B.; Pforte, H.; Jacobasch, G.; Derendorf, H.; Veit, M. Pharmacokinetics and bioavailability of quercetin glycosides in humans. J. Clin. Pharmacol. 2001, 41, 492-499. [CrossRef] [PubMed] 